MUSHIRUL HASAN

\title{
Memories of a Fragmented Nation: Rewriting the Histories of India's Partition ${ }^{* 1}$
}

Today I am asking Waris Shah to speak from the grave,

To turn the page of the book of love. Once the daughter of the Punjab wept, and you wrote endlessly.

Today Lakhs [Ioo,ooo] of daughters are weeping and they are imploring you Waris Shah

Get up, you who sympathise with our grief, get up and see your Punjab.

Today there are corpses everywhere, and the Chenab is filled with blood.

Somebody has mixed poison in all the five rivers,

The rivers we use to water our fields ...

$$
\text { -Amrita Pritam }
$$

"We apologize to our readers for a few incomplete citations and occasional ambiguities in this article. Unfortunately the author was unavailable for consultation. The unclear or incomplete material is marked by "[?]."-Editor

${ }^{1}$ This paper does not cover the historical writings on the Bengal province, especially Bangladesh where the histories of Partition are being written differently since 197I. See, for example, Willem van Schendel and Erik Jan Zürcher, eds., Opting Out of the Nation: Identity Politics in Central, South and West Asia (London, 1998). 


\section{4 - The Annual of Urdu Studies}

When I think of Lahore, I go back to the days of my youth just before the Partition. Life then was so romantic, slow, deep and beautiful. Really, they were good times, they were great times.

$$
\text { -Krishna Sobti }{ }^{2}
$$

I hope that one day [...] displaced families on both sides of the fence will at least be able to freely cross the borders and show their grandchildren where their grand parents had once lived and belonged. The day such a change comes about, I shall be the first to cross the Wagah or Hussainiwallah border posts to take my grand-daughter to Lahore, and show her the home of my youthful dreams-

$$
\text { -N.N. Vohra }{ }^{3}
$$

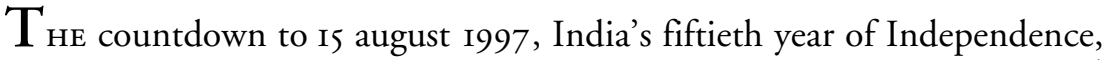
generated an extraordinary interest in plotting the history of Partition. ${ }^{4}$ One wonders why painful memories and traumatic experiences were revived on such an occasion, why the nostalgia and the celebration of the

"In Conversation with Alok Bhalla," in Crossing Boundaries, ed. Geeti Sen (Delhi, I997), p. 78.

3“91, Garden Town," in ibid., p. 54.

${ }^{4}$ Some years ago, the historian Gyanendra Pandey complained that the history of violence accompanying Partition had not been written. As his Nandy [?] bemoans that the finest creative minds of India had maintained a profound, almost cultivated silence about Partition and the bloodbath (cf. Times of India [20 July I997]). See also, Urvashi Butalia, "Official Silence," Hindu (Delhi; 2I September 1997). My principal interest in this essay centers around articles published in newspapers, magazines and journals during the fiftieth year of Independence. In addition, I have drawn attention to some scholarly writings, mostly published in 1996-97, on Partition.

The Delhi-based weekly newsmagazine, Outlook, brought out a special issue on 28 May 1997. The Asian Age, edited by M.J. Akbar, published extracts from books on Partition, personal memories and recollections and interviews. See, for example, the reports of the Reuters correspondent Don Campbell who arrived in India in March 1947 and spent the next 15 months in Delhi. The coverage in the newspaper Hindu was also quite extensive. The impressions of Phillips Talbot, an American, were published in this newspaper. 
dead. ${ }^{5}$ Was it because there was not much to celebrate? Or did the occasion itself finally sensitize sections of the intelligentsia to the painful legacy of a brutal past. Amrita Pritam, the noted Punjabi writer who lived in Lahore before moving to Delhi in 1947 and whose celebrated poem quoted in the epigraph became one of the most influential and representative works of Partition, recalled:

What I am against is religion - the Partition saw to that. Everything I had been taught—about morals, values and the importance of religion-was shattered. I saw, heard and read about so many atrocities committed in the name of religion that it turned me against any kind of religion and revolution. ${ }^{6}$

Sure enough, a common refrain in popular and scholarly writings was that the country's division was a colossal tragedy, a man-made catastrophe brought about by hot-headed and cynical politicians who failed to grasp the implications of division along religious lines. ${ }^{7}$ For a change, the focus was on the popular experiences of violence and displacement, ${ }^{8}$ on the impact of Partition on the lives of hundreds of millions, including the

${ }^{5}$ For example, Urvashi Butalia, "Blood," in Granta (London; March 1997); Sunil Mehra, "Sufferers and Survivors," Outlook (28 May 1997), pp. 32-3; "Bridging a Great Divide," India Today (I8 August 1997); Anita Mukhopadhya, "The Last Journey," Hindu (3I August 1997); Ajeet Cour, "I've Seen Rootless Trees Wobbling and Walking," Hindustan Times (4 January 1998) (Courtesy: Nonica Datta); C.M. Naim, "Pakistan or Hindustan," Communalism Combat (September 1997); "India’s Unforgettable Divide," Guardian (London; 30 July 1997); Iqbal Masud, Dream Merchants, Politicians and Partition: Memoirs of an Indian Muslim (Delhi, 1997).

${ }^{6}$ Femina (Bombay; I August 1997). I am grateful to Nonica Datta for this reference.

${ }^{7}$ For example, Patrick French, Liberty or Death: India's Journey to Independence and Division (London, 1997).

${ }^{8}$ See, for example, the scholarly contributions of Gyanendra Pandey, "Community and Violence," Economic and Political Weekly (EPW; 9 August 1997) and "Partition and Independence in Delhi: 1947-48," EPW (6 September 1997); also, Azhar Abbas, "The Twice Displaced," Outlook (28 May 1997), p. 66. For insights into ethnic violence in Sri Lanka in 1983 that had many features in common with the Hindu-Muslim riots before and after Independence, see S.J. Tambiah, Ethnic Fratricide and the Dismantling of Democracy (Chicago, 1986). 
trauma of women, ${ }^{9}$ and the great variety of meanings they attached to the upheaval in and around their homes, fields and factories. ${ }^{10}$ Although one should not make much of this shift in emphasis, the inclination to sideline the tall poppies in the Partition debates was in large part an expression of the growing disillusionment with high politics and its postcolonial practitioners.

The mood reflected in popular literature was decisively against the leaders of the Subcontinent and their inability to resolve their perennial disputes over power-sharing. Doubtless, the colonial government's rôle in heightening Hindu-Muslim rivalries and the "communal" implications of Bengal's partition in 1906 were recounted. So also the political blunders committed by Wavell during his inglorious years in the viceregal lodge, the impetuousness of Mountbatten who reveled in his rôle as arbiter, the destiny of millions sitting light on him, the collapse of the law and order machinery which was kept in a state of readiness to protect the Europeans but not the hapless victims of a civil war, and, finally, the arbitrary demarcation of the border by a British jurist who had neither been to India nor shown interest in Indian affairs. "Nothing could illustrate," commented the senior journalist Ajit Bhattacharjea, "the callous haste with which Partition was pushed through more strikingly than the lastminute arrangements to demarcate the border." ${ }^{\prime 2}$

${ }^{9}$ Butalia; Ritu Menon and Kamla Bhasin, Borders \& Boundaries: Women in India's Partition (Delhi, Kali for Women, 1998).

${ }^{10}$ Mushirul Hasan, Legacy of a Divided Nation: India's Muslims Since Independence (London, 1997), and India Partitioned: The Other Face of Freedom 2nd rev. ed. (Delhi, Roli Books, 1997).

${ }^{11}$ For a critique of Mountbatten, see N.N. Vohra, and F.S. Aijazuddin "'Same to Same' from a different perspective," in Sen.

${ }^{12}$ Outlook (28 May 1997). Notice the following letter of Cyrill Radcliffe to his son: "I thought you would like to get a letter from India with a crown on the envelope. After tomorrow evening nobody will ever again be allowed to use such stationery and after 150 years British rule will be over in India. [...] I am going to see Mountbatten sworn as the first governor-general of the Indian Union [...] and then I station myself firmly on the Delhi airport until an aeroplane from England comes along. Nobody in India will love me for the award about the Punjab and Bengal and there will be roughly 80 million people with a grievance who will begin looking for me. I do not want them to find me. I have worked and travelled and sweated —oh I have sweated the whole time." Quoted in Sunil Khilnani, The Idea of India (London, 1997), p. 201. 
According to the same writer, the onus none the less rested on the Indian leaders, many of whom were primarily interested in ensuring that the transfer of power was not delayed and were therefore "unaware and uncaring of the human cost of cutting a border through the heart of populous provinces." 13 Illustrating Jawaharlal Nehru's "lack of touch with grassroots reality" and his "self-delusion" that Pakistan would be compelled by its limitations to return to the greater Indian fold, ${ }^{14}$ Bhattacharjea recalled what Nehru told the author Leonard Mosley.

"We were tired men," India's first Prime Minister said in 1960, "and we were getting on in years too. Few of us could stand the prospect of going to prison again — and if we had stood out for a united India as we wished it, prison obviously awaited us. We saw the fires burning in the Punjab and heard of the killings. The plan of Partition offered a way out and we took it. [...] We expected that Partition would be temporary, that Pakistan was bound to come back to us." ${ }^{15}$

With the focus on high politics, the same old story does the rounds with unfailing regularity. The engagement continues to be with the "major" political actors of the I930s and I940s, who conducted their deliberations lazily in cozy surroundings and presided over the destiny of millions without their mandate. One is still encumbered with the details of what went wrong and who said what from the time the First Round Table Conference was held in London in 1930. Thanks to the publication of the voluminous transfer of power documents and the works of Gandhi, Nehru, Mohammad Ali Jinnah, Vallabhbhai Patel and Rajendra Prasad, the spotlight remains on the "mystery" behind the protracted and tortuous negotiations triggered by the Cripps offer and the Cabinet Mission. ${ }^{16}$ The bitter and acrimonious exchanges thereafter, which have all along dominated the historiography on nationalism, "communalism" and "Muslim separatism," continue to haunt present-day writers. The search for the "guilty men," based on personal reflections/memories or the blunt

\footnotetext{
${ }^{13}$ Ajit Bhattacharjea, "Cyril's Scalpel," Outlook (23 July 1997), p. 8.

${ }^{14}$ Thus the following view: "Looking back 50 years, the haste and self-delusion of Congress and Muslim leaders that contributed to the bloodiest religious cleansing in history emerges with disturbing clarity"-Outlook, (28 May 1997).

${ }^{15}$ Leonard Mosley, The Last Days of the Raj (London, 1961), p. 77.

${ }^{16}$ For example, the presidential address delivered by Professor V.N. Datta at the Indian History Congress held in Madras, 1996.
} 
testimony of the socialist leader Ram Manohar Lohia and the guarded "revelations" of Maulana Abul Kalam Azad, goes on relentlessly. ${ }^{17}$ As a result, the historians history of Partition

is not a history of the lives and experiences of the people who lived through that time, of the way in which the events of the I940s were constructed in their minds, of the identities and uncertainties that Partition created or reinforced. ${ }^{18}$

These concerns are not so widely reflected in Pakistan, where it is conveniently assumed that the "Partition issue," so to speak, was resolved well before 1947 by the weight of the two-nation theory. ${ }^{19}$ The result is for everybody to see. Although Jinnah of Pakistan has been elevated to a high pedestal by the Cambridge-based scholar Akbar Ahmad, he would remain, unless rescued from his uncritical admirers, a lonely figure in the pages of history and in the gallery of nation-builders. If the desire is to

${ }^{17}$ Kuldip Nayar, "Was Pakistan Necessary?" Indian Express (I5 August 1997), and "Partition: An Inevitability," Hindu (Special Issue on "India!"; August 1997). For earlier accounts of who is to blame, see Chimanlal Setalvad, India Divided (Bombay, n.d.), pp. 4-7.

${ }^{18}$ Gyanendra Pandey, "The Prose of Otherness," in Subaltern Studies VIII: Essays in Honour of Ranajit Guha, ed. David Arnold and David Hardiman (Delhi, I994), p. I94.

${ }^{19}$ This is the common refrain in the writings of Ayesha Jalal and Farzana Shaikh. For a critique of Jalal's work, see Gyanendra Pandey, "The Prose of Otherness," pp. 209-IO; and for Jalal's response, "Secularists, Subalterns and the Stigma of 'Communalism': Partition Historiography Revisited," The Indian Economic and Social History Review, 33.I (1996): pp. 93-I03. The tendency to exaggerate the difference in perspectives and to castigate each other for that reason appears to be the hallmark of recent historiography on South Asia. Young and upcoming social scientists, many of whom have not even written their doctoral dissertations, are engaged in polemical writings. Many regard this as a shortcut to establishing their "scholarly" reputation in the West. Many have developed the lazy habit of writing "critiques" without any archival research.

Ayesha Jalal's critique of my introduction to India's Partition: Process Strategy and Mobilisation (Delhi, 1993) is based on a misunderstanding of my overall argument. Yet, I respect her views and her disagreement with some of my formulations. In other words, my basic contention is that our reading of a highly complex phenomenon should not be reduced to polemical exchanges among social scientists. 
come to terms with his political engagement and explain his extraordinary success, it is not at all helpful to press him into service to establish Pakistan's identity as an Islamic state. Likewise, the use of religious symbols, long forsaken by that country's bureaucracy and military establishment, can hardly serve as the starting point for a meaningful dialogue on Partition.

The engagement of several writers in India, though sometimes marred by a majoritarian perspective, centers around "secular nationalism," the main inspiration behind much of liberal-left activism from the I920s onwards. Their chief concern, though nowadays pooh-poohed in the "post-modernist" discourse, is to examine why the secular élites and their ideologues, whose presence is grudgingly recognized across the ideological divide, failed to mediate between those warring factions/groups who used religion as a cover to pursue their worldly goals and ambitions. While detailing the cynical games played out on the Indian turf by the British, the League and the self-proclaimed "nationalists" of every variety, they do not spare the Congress stalwarts, Gandhi, Nehru and Patel included, for their failure to guide the movements they initiated away from the forces of reactionary communalism. ${ }^{20}$ They marshal a wide array of sources to comment on Hindu communalists disguising themselves as Congressmen and preventing the national movement from becoming truly inclusive. They also point to Gandhi's rôle in introducing religion into politics, the anti-Muslim proclivities of the Hindu right, led by Patel in the I940s, the Hindutva agenda of the Hindu Mahasabha, the Arya Samaj and the RSS (Rashtriya Swayam Sewak Sangh), and Nehru's arrogance and haughtiness in dealing with Jinnah and the Muslim League. At a time when the Muslim League was flexing its muscles,

\footnotetext{
${ }^{20}$ In a perceptive article, Aijaz Ahmad has offered a powerful critique of "the Congress-inspired mythology." His analysis suggests (a) that the politics of caste and communalism was inherent in the structure of the colonial society itself; (b) that the reform movements usually contributed to solidifying such identities rather than weakening them in favor of ecumenical culture and a nondenominational politics; and (c) that the national movement itself, including the majority of the Congress under Gandhi, was deeply "complicit in a transactional mode of politics which involved bargaining among the elites and a conception of secularism which was little more than an accommodation of the self-enclosed orthodoxies. Given the immensity of this historical weight, the wonder is not that there was a partition but that there was one" (emphasis added) [?]; Hindu (Special Issue on "India!"; August 1997), p. 28.
} 
India's first Prime Minister is said to have jettisoned the plan for a Congress-League coalition in 1937 and dimmed the prospect of an enduring Hindu-Muslim coalition in Indian politics. Thus the mainstay of the argument is that the country's vivisection could have been avoided had Nehru acted judiciously on this and other critical junctures in the I940s. ${ }^{21}$

Though such impressions rest on questionable assumptions, they cannot be brushed aside. ${ }^{22}$ The real difficulty lies with the grand narrative itself and the tendency to generalize on the basis of the actions of a few. While the grand narrative illuminates several facets of the Pakistan story, it fails to incorporate the complexities and subtleties of institutional and structural changes introduced by the colonial government, as also the impact of socio-economic processes on caste, class and religion-based alignments. One does not, moreover, get a sense of why the two-nation theory was floated in March 1940 and not earlier, why and how different forms of identities and consciousness got translated into a powerful campaign for a separate Muslim homeland, why Partition created ten million refugees, led to the death of over a million people, and resulted in sexual savagery, including the rape and abduction of 75,000 women. Finally, the grand narrative does not reveal how the momentous happenings in August-September 1947 affected millions, uprooted from home and field and driven by sheer fear of death to seek safety across a line they had neither drawn nor desired. Clearly, the issue is not whether a million or

\footnotetext{
${ }^{21}$ The judgment is harsh, though many contemporary observers believed that Jinnah may not have had the space to press his campaign in the United Provinces if the coalition issue had been amicably resolved. The lieutenant-governor of UP felt that way, for which, see "Harry Haig to Linlithgow" (3 June 1939), File no. II5/6, IOLR, and my introduction to India's Partition, pp. I2-5.

${ }^{22} \mathrm{On}$ the coalition issue, there is unmistakable evidence to suggest that talks for a Congress-Muslim League alliance were initiated sometime in March-April 1937. Though Nehru had opposed "all pacts and coalitions with small groups at the top." ("To Abdul Wali," 30 March 1937, All India Congress Committee [AICC] Papers, G-5, K.W i, 1937, Nehru Memorial Museum \& Library), Abdul Wali of Barabanki (UP) referred to a scheme "being hatched with the help of Pantji [G.B. Pant] and Mohanlal [Saxena] to bring about coalition between the Congress and League parties in the Assembly." (To Nehru, 28 March 1937, AICC Papers.) The lieutenant-governor of UP reported on 7 April that the League was looking forward to an alliance with the Congress and felt that "at present it looks as if the new government will gradually attract to itself a fair number of the Muslim Leaguers.”
} 
more died or whether only 3 percent of the country's population was affected by the communal eruption. The essential facts, as pointed out by the chief of the governor-general's staff, were that "there is human misery on a colossal scale all around and millions are bereaved, destitute, homeless, hungry, thirsty-and worst of all desperately anxious and almost hopeless about their future." [?]

In order to explore some of these aspects and probe those areas which directly or indirectly impinged on the sudden and total breakdown of long-standing inter-community networks and alliances, it is necessary to locate the Partition debates outside the conference chambers. Without being swayed by the paradigms set by the two-nation theory or the rhetoric of Indian nationalism, it is important to examine why most people, who had so much in common and had lived together for generations, could turn against their neighbors, friends and members of the same caste and class within hours and days. Such tragedies have taken place in the former state of Yugoslavia, but it is unclear why they have gone unnoticed at research centers in the Subcontinent, especially in the areas most affected by gruesome violence and migration. Is it because the ghosts of Partition should be put to rest and not exhumed for frequent post-mortems? Or, is scholarship on the subject itself so woefully inadequate and contentious that it fails to excite the imagination of young graduates?

Perspectives and attitudes on such vexatious matters are bound to differ, though scholars in Pakistan tenaciously adhere to the belief that the creation of a Muslim nation was a legitimate act, the culmination of an historical process. Perhaps, it is hazardous to contest such inherited wisdom in a society where nationality is still defined, often clumsily, in purely Islamic terms, and religious minorities, Hindus and Ahmadiyas (Qadianis) included, are left to stew in their own juice. Perhaps, Partition does not convey the same meanings in Lahore and Islamabad as it does to some people living in Delhi, Lucknow, Calcutta and Dacca. It is not bemoaned, for understandable reasons, as an epic tragedy but celebrated as a spectacular triumph of Islamic nationalism. After all, why should people inhabiting the fertile districts of western Punjab or the rugged Frontier region mourn the break-up of India's fragile unity or lament the collapse of a common cultural and intellectual inheritance? Some beleaguered muhājirs may still want to recall their friendships and associations in Hindustan (guzashta bāda-parastōin $k \bar{\imath} y \bar{a} d g \bar{a} \bar{r} k \bar{o} \hat{\imath})$, trace their intellectual and cultural links with Lucknow or Delhi, and occasionally revive memories of a bygone era by dipping into the writings of Saadat Hasan Manto, 
Ahmed Ali, Josh Malihabadi, Qurratulain Hyder and Intizar Husain. ${ }^{23}$ Yet the nostalgia for what has already become an imaginary homeland or the identification with Lucknow's grand imambāras or with the Șüfi shrines of Khwaja Muinuddin Chishti at Ajmer and of Nizamuddin Auliya in Delhi is gradually fading away with the passage of time and the passing of a generation. The Badshahi mosque, standing majestically as a symbol of India's secular dream, is as distant and remote as the Masjid-e Qurtaba, the theme of Mohammad Iqbal's melodious poem. Aminabad in Lucknow or Ballimaran in old Delhi are far removed from the imagination of a generation that has grown up in a different social and cultural milieu.

The differences in approaches and perspectives should not, however, stand in the way of developing a common reference point for rewriting the histories of an event that cast its shadow over many aspects of state and society in the Subcontinent. Despite decades of mutual suspicions and antipathies that have led to a mindless arms buildup and contributed to the backwardness and appalling poverty of the region, it is still possible for the peoples, rather than the governments, to make sense of the poignant works of creative writers and poets and to reflect on how and why a generation was caught up in the crossfire of religious bigotry, intolerance and sectarianism. Such an exercise can be undertaken without calling into question the legitimacy of one or the other varieties of nationalisms.

For the initiative to get off the ground, it may be useful to revisit the old-fashioned theories on the syncretic and composite trajectory of Indian society and detail, as the writer Krishna Sobti does in her recent interview, the shared values and traditions that had enabled diverse communities to live harmoniously for centuries. ${ }^{24}$ It is not necessary to be swayed, as is often the case, by the "nationalist" historians who portrayed an idyl-

\footnotetext{
${ }^{23}$ See Masud Hasan Shahab Dehlavi, in India Partitioned, ed. Mushirul Hasan, Vol. II, pp. I84-95.

${ }^{24}$ Sen, p. 66. See also the following comment of J.S. Butalia, a retired journalist: "I was born and brought up in a predominantly Muslim village, Butala. There were 300 Muslim families and only ro or I5 Hindu homes but we lived in such close harmony that it was difficult to make out who was who. A HinduMuslim conflict was something we had not imagined even in our worst dreams. It is with a sense of horror and shame that I look back [...] but, finally, I am overwhelmed by nostalgia"-Hindu (Special Issue on "India!"; August 1997), p. 32. For Bengal, see Mukhopadhaya, “The Last Journey," Hindu (3I August 1997).
} 
lic picture of Hindu-Muslim relations during the pre-colonial days in order to strengthen inter-community ties during the liberation struggle. It is none the less important to underline, despite valiant attempts to uncover the "Pre-History of Communalism," the fusion and integration of the Hindu communities at different levels and the value they attached to religious tolerance and pluralism in their day-to-day living. ${ }^{25}$ In so doing, one can put to rest those speculative theories that are designed to lend respectability to British colonialism and offer a corrective to the distorted Islamist or the Hindutva world-views which have, in equal measure, created widespread confusion in the minds of the common people and, in the process, caused incalculable damage to state and civil society.

The conclusions flowing from such formulations are bound to differ, yet the urgency to underline the commonality of interests amongst large segments of the population must be felt in India where Hindutva could well be the new mantra of civil society in the foreseeable future, and in neighboring Pakistan, where ethnic and sectarian strife, combined with deep-seated regional and linguistic cleavage, reveal the limits of an agenda that is tied to wild and imaginary notions of Muslim/Islamic brotherhood or solidarity.

II

The following three impressions are drawn from a period when HinduMuslim relations had reached their lowest watermark. The first is of Malcolm Darling, a civil servant in Punjab for many years. During his travel in 1945-46, he found much similarity between the Hindu and Muslim communities in the tract between the Beas and Sutlej and the Chenab and Ravi rivers. He noticed, something he had done on numerous occasions during his long career as a British civil servant, how often Hindus, Muslims and Sikhs had a common ancestor in a village, how a Hindu from Karnal proudly announced that the Muslim inhabitants of the fifty neighboring villages belonged to his clan and were prepared to return to the Hindu fold on the one condition that the Hindus would give them their daughters in marriage. Although the condition was refused, Hindus

\footnotetext{
${ }^{25}$ See the contributions of Rakshat Puri, Muchkund Dubey and Sumanta Banerjee, in Sen.
} 
and Muslims of the area continued to interchange civilities at marriage, inviting the mullah or the Brahman, to share in the feasting. Malcolm Darling wondered how was Pakistan to be fitted into these conditions. "What a hash politics threatens to make of this tract," he observed, "where Hindu, Muslim and Sikh are as mixed up as the ingredients of a well-made pilau (rice cooked with fowl or meat)."26

Mohammad Mujeeb, the vice-chancellor of Delhi's Jamia Millia Islamia, had a similar experience in Bihar soon after the orgy of violence had taken a heavy toll of human lives. While visiting the grave of a Șūfì saint on the banks of the river Ganges, he found that the Muslims living in the shrine had already abandoned the place. But soon a group of Hindu women appeared. They performed the same rituals that their ancestors had observed for generations. It appeared "as if nothing had happened that affected their sentiments of veneration for the tomb of a Muslim saint." ${ }^{27}$

Finally, consider the reports of Phillips Talbot, written for the Institute of Current World Affairs in New York on the eve of Independence and published recently in the daily newspaper, Hindu. For one thing, Talbot was struck by the countrywide expression of Hindu-Muslim cordiality during the Independence celebrations.

For twenty long and bloody weeks after I6 August, 1946, Hindus avoided entering Muslim neighbourhoods and vice versa. Communal clashes and deaths were daily occurrences. Yet at the climax of Independence celebrations this week, Hindus and Muslims mixed together freely. Many Hindus visited mosques on the I8th and distributed sweets to Muslims who were observing their Id festival [...] It was a spectacular truce, if not a peace treaty, between the two communities. Similarly, in Delhi and Bombay I saw Hindus and Muslims playing hand in hand. Reports of the same nature came from most places except the still-troubled Punjab. ${ }^{28}$

${ }^{26}$ This is quoted in full in my Legacy of a Divided Nation, p. I68.

${ }^{27}$ See my India's Partition: Process, Strategy and Mobilisation, p. 405. For Punjab, see Sobti in Sen, pp. 67, 69-70, for Bengal, Reflections on Partition in the East, ed. Ranabir Samaddar (Delhi, I997), and its reviews by Sumanta Banerjee in Biblio (Delhi; July-August 1997), pp. 40-I, and Peter Van Der Veer, "Playing or Praying: A Sufi Saint's Day in Surat," The Journal of Asian Studies, 51.3 (August 1992): 545-64.

${ }^{28}$ Phillips Talbot, "Thus Independence Came to India," Hindu (4 and 24 August 1997). 
Talbot's own explanation was that the political parties desired peace and friendship between the communities, though he laid greater stress on "the popular revulsion against the constant dislocation and actual fear of life during the last year." "Terror," he added,

is an enervating emotion. I've seen neighbourhoods so distraught by the medieval lack of personal security that they could think of nothing else. I think that people everywhere used the excitement of the celebrations to try to break the vicious cycle of communal attacks and retaliations. How permanent the change may be is yet to be seen. ${ }^{29}$

Such impressions need to be drawn into the discussions on Partition so that the past is not judged through our recent encounters with HinduMuslim violence in India. It is just as important to delineate the multiple strands in the Muslim League movement, underline its complexity, assess its ideological orientation afresh, and explore the mobilization strategies adopted by Jinnah after he returned from his home in Hampstead to plunge into the humdrum of Indian politics. In addition to having greater access to source materials, this is an opportune moment, fifty years after Independence, to revise and reconsider established theories on Partition, introduce a more nuanced discourse, and stay clear of the conventional wisdom that we, the generation born after Independence, have inherited on the theme of "communal" politics generally and the Pakistan movement in particular. As "old orthodoxies recede before the flood of fresh historical evidence and earlier certitudes are overturned by newly detected contradiction," this is the time to heal "the multiple fractures which turned the promised dawn of freedom into a painful moment of separation." 30

For example, one of the points adequately documented, though not sufficiently considered in secondary literature, is that not everyone who raised or rallied around the green flag was uniformly wedded to or inspired by a shared ideal of creating an Islamic society. The reality is that many were pushed into taking religious/Islamic positions, while many others, especially the landed classes in Punjab and the United Provinces (UP), used the Muslim League as a vehicle to articulate, defend and promote their material interests. In fact, the intensity of emotions expressed

\footnotetext{
${ }^{29}$ Talbot filed this report on Io August 1947.

${ }^{30}$ I have borrowed these lines from Ayesha Jalal, "Secularists, Subalterns and the Stigma of 'Communalism,"' p. I.
} 
in the 1940s, which is so often invoked in the Subcontinent to create popular myths and stereotypical images, had more to do with the political and economic anxieties of various social classes than with a profound urge to create a Shari ${ }^{-} a$-based society. Today, the issue is not the legitimacy of a movement but to place in perspective the dynamics of power-politics in a colonial context. In fact, a rounded picture of the Pakistan movement is possible only if we are able to contest the exaggerated claims made in the name of Islam, then and now, by the Islamists and the proponents of the two-nation theory.

In sum, the clamor for a separate nation, though pressed vigorously in the post-war years with much popular backing and enthusiasm, was raised not so much by the Muslim divines, many of whom were waiting on the fringes of Indian politics to intervene on behalf of Islam, but by the vociferous professional groups in Uttar Pradesh, Bihar, the princely state of Hyderabad, and the small but upcoming trading and banking communities in Gujarat, Bombay and Calcutta. Interestingly enough, the Muslim landlords of UP were the first to raise the banner of revolt against the League; in fact, the Nawab of Chattari and Nawab Mohammad Yusuf of Jaunpur broke away from the Muslim League Parliamentary Board in April 1936 in order to revive "a mixed party in preference to a Muslim communal organisation." ${ }^{31}$ They changed course once the Congress Ministry adopted the UP Tenancy Bill and Nehru and his comrades became more and more strident in their socialistic pronouncements. These men were not concerned to defend the Qur'anic injunctions which they probably flouted every day of their lives. Nor were they interested in the welfare of the poor Muslims, who were victims of their oppression and exploitation. Their chief goal was to defend their landholdings, orchards, havēliss, palaces and, above all, the navābi paraphernalia built through the courtesy of their British benefactors. Notice the following conversation between Saleem and his father Hamid in Attia Hosain's (d. 1998) novel Sunlight on a Broken Column:

Saleem was saying, "In the final analysis, what you are facing is the struggle for power by the bourgeoisie. It is not really a peasant's movement, but when it comes to a division of spoils even class interests are forgotten. For example the four hundred or so Taluqdars insisted the British

\footnotetext{
${ }^{31}$ Nawab of Chattari to Hailey, 28 October 1936, Malcolm Hailey Papers, File no. 28c, IOLR.
} 
should give them higher representation than the thousands of other landlords."

"It is not a question of numbers alone," protested Uncle Hamid, sitting up and waving his pipe in negation. "We Taluqdars have ancient rights and privileges, given by a special charter, which we have to safeguard." [...]

"Yes, yes, of course. One respects tradition. One fights for one's self, one's interests. But you cannot expect the tenants to love you for it."

"That is because so-called reforms are destroying the personal ties between landlord and peasant. Surely a Government and its changing officers cannot have personal relations or traditional ties with the tenants? With whom are the people in constant touch? Their landlords or local political leaders?" [...]

"How can landlords but be uneasy at the thought of such reserves of power being vested in officials at a time when it is uncertain what class of persons will obtain political power?” (Uncle Hamid) [...]

Saleem could not let an argument die an unnatural death. He began, "What you said, father, about the landlords' fear of abolition is the crux of the matter. This fear for their existence is the basis for the formation of a new party which is interested in keeping the status quo intact, that is favoured by the British and is fundamentally opposed to progressive, national movements. [...]"

"Words? Theories! Irresponsible talk!" Uncle Hamid burst out. "I am a part of feudalism, and proud to be. I shall fight for it. It is my heritage-and yours. Let me remind you of that. And that you enjoy its 'reactionary' advantages. You talk very glibly of its destruction, but you live by its existence. It is, in fact, your only livelihood." ${ }^{\prime 32}$

No wonder, the landed elements in UP, as also the Jamā'at-e Islāmi and sections of the 'ulama' connected with the Barelvi "school," Nadvatu 'l-'Ulamā', Firangi Mahal and Deoband, hitched their fortunes with the Muslim League at different points of time and for different reasons. Their overall strategy, one that suited the Raj during and after World War II, was to masquerade their hidden agenda and project the Congress, their main rival in the political world, as a "Hindu" party inimical to Islam. Once the League bandwagon rolled on, other aggrieved groups, especially those who failed to secure employment, contracts or seats on regional and

\footnotetext{
${ }^{32}$ (Delhi, 1992), pp. 23I-4
} 
local bodies, jumped into the fray as the defenders of the faith.

Still, Pakistan was not everybody's dream. Nor was Jinnah everyone's Qaid (leader). ${ }^{33}$ In this respect, one should not, as is generally the case with both the Hindu and Muslim majoritarian discourses, lose sight of the perspectives of those who were intellectually committed to secular nationalism or were actively engaged in repudiating the two-nation theory. Their voices, which have been stifled by "secular" as well as "communal" histories, should not be relegated to a historian's footnote. Indeed, the part played by those Muslims, who are patronizingly described as "Nationalist Muslims," the Khudā'̄̄ Khidmatgārs in the North-West Frontier region, who were eventually let down by the dispirited Congress leadership on the eve of Independence, the 'ulama' of Deoband and the Momins in Bihar, should not be submerged beneath the rationalization of the "victors." Their main contribution, exemplified by Maulana Abul Kalam Azad's exemplary conduct and performance, ${ }^{34}$ was to keep alive the vision of a secular India. These "marginal" voices must be recovered to rewrite the histories of Partition. ${ }^{35}$

For these and other reasons, it is appropriate to ask if the Muslim League movement was as cohesive and unified as it is made out to be by some writers in India and Pakistan. If the Congress was faction-ridden and ideologically fragmented, so was the League. ${ }^{36}$ This is illustrated by

\footnotetext{
${ }^{33}$ In this respect, my reading of the Pakistan movement is different from that of Ayesha Jalal.

${ }^{34}$ The following impression of Azad by Kanji Dwarkadas is interesting. "Abul Kalam Azad," he wrote, "is dignified and level-headed, but his health is giving way. Jinnah dislikes him heartily and a few years ago he called him the 'show boy' of the Congress and in private conversations Jinnah says much worse things about Abul Kalam Azad"; see his "India-April 1944 to November 1945: What Next?" 28 November 1945 (Typescript), George Lumley Papers, India Office Library and Records, London.

${ }^{35}$ See Pandey, "The Prose of Otherness," p. 2 I4.

${ }^{36}$ In fact, Jinnah exhorted various regional groups and other factions to overcome their differences and rival claims so that the Muslim League could concentrate all its energies towards the achievement of Pakistan. "We shall have time to quarrel ourselves," he said, "and we shall have time when these differences will have to be remedied. We shall have time for domestic programmes and politics, but first get the Government. This is a nation without any territory or any government"; quoted in Khalid B. Saeed, Pakistan: The Formative Phase, 1857-1948 (London, 1968), p. 297.
} 
the depth and intensity of jealousies and internal discord in the organization, the regional groupings, the Ajlāf-Ashrāf divide, the Shī'a-Sunnī strife in many places, and the unending doctrinal disputes between the theologians and the followers of the Barēlvī and the Dēobandī "schools." Such differences, which are conveniently overlooked in the histories of the freedom movement in Pakistan, were real and not imaginary. If so, it will not do to portray the Muslim Leaguers as earnest and self-sacrificing crusaders or equate them with the Muhājirs or Anșārs of the Prophet Muhammad. What is perhaps challenging, as indeed intellectually rewarding, is to probe those critical areas where the "faithful," despite having projected themselves as a community acting in unison, were themselves so hopelessly split. Such an exercise, far from reducing or tarnishing the reputation of historic figures, would enrich our knowledge and understanding of a complex phenomenon. Arguably, if we know our leaders better and question their reading of the authentic and vibrant histories of shared memories and experiences, we may not repeat their mistakes and errors of judgment which cost the nation dearly at the stroke of the midnight hour on I4-I5 August 1947.

\section{III}

The decision about the creation of Pakistan had just been announced and people were indulging in all kinds of surmises about the pattern of life that would emerge. But no one's imagination could go very far. The sardārji sitting in front of me repeatedly asked me whether I thought Mr Jinnah would continue to live in Bombay after the creation of Pakistan or whether he would resettle in Pakistan. Each time my answer would be the same, "Why should he leave Bombay? I think he'll continue to live in Bombay and continue visiting Pakistan." Similar guesses were being made about the towns of Lahore and Gurdaspur too, and no one knew which town would fall to the share of India and which to Pakistan. ${ }^{37}$

In the specific context of the Pakistan movement, the professed ideology

\footnotetext{
${ }^{37}$ Bhisham Sahni, "We have Arrived in Amritsar," Stephen Alter and Vimal Dissanayake, ed. The Penguin Book of Modern Short Stories (Delhi, 1989), pp. I80-7.
} 
of the nation-state itself, though celebrated on both sides of the border, had no significant impact on or relevance to the millions living in India or Pakistan. Contrary to the exaggerated claims made in both countries, most people were either indifferent to or unconcerned with the national borders or the newly-created geographical entities that were being laboriously created. National borders were political constructs, imagined projections of territorial power. Although they appeared in deceptively precise forms, they reflected, at least initially, merely the mental images of politicians, lawyers, and intellectuals. Their practical consequences for most people were quite different. ${ }^{38}$ Rajinder Sachar, jurist and human rights activist who has spent a lifetime struggling with his memories of Lahore, recalled:

One day I ran into a Muslim villager who had come to Lahore all the way from Sargodha looking for my grandfather, a well-known criminal lawyer. Poor chap he didn't realise that Partition had taken place and that the Hindus had left. It just shows how long it took for the implications of Partition to sink in. ${ }^{39}$

Indeed, though such people were repeatedly fed with ill-informed and biased views and interpretations about the other, they were neither committed to the land of Aryavarta nor the dār al-Islām. They had no destination to reach, no mirage to follow. Even though the trains had started carrying people to their death-traps, they were unclear whether Lahore, with its splendid Mughal monuments, beautiful gardens and boulevards, would be part of India or Pakistan. They did not know whether Delhi, the city of Mīr Taqī Mīr and Mirzā Ghālib, would remain in Gandhi's India or become part of Jinnah's Pakistan. Manto captures the mood in his brilliant story "Ṭōba Ṭēk Singh," named after a character from the lunatic asylum. This is what he writes:

As to where Pakistan was located, the inmates knew nothing. That was why both the mad and the partially mad were unable to decide whether they were now in India or in Pakistan. If they were in India where on earth was Pakistan? And if they were in Pakistan, then how come that

\footnotetext{
${ }^{38}$ These lines are based on Michiel Baud \& Willem Van Schendel, "Towards a Comparative History of Borderlands," in Journal of World History, 8.2 (1997): $2 \mathrm{II}-42$.

${ }^{39}$ Quoted in Hindu (Special Issue on “India!"; August 1997), p. 28.
} 
until only the other day it was India? [...]

Those who had tried to solve this mystery had become utterly confused when told that Sialkot, which used to be in India, was now in Pakistan. It was anybody's guess what was going to happen to Lahore, which was currently in Pakistan, but could slide into India any moment. It was still possible that the entire subcontinent of India might become Pakistan. And who could say if both India and Pakistan might not entirely vanish from the map of the world one day? [...]

Just before sunrise, Bisham Singh, the man who had stood on his legs for fifteen years, screamed and as officials from the two sides rushed towards him, he collapsed on the ground.

There, behind barbed wire, on one side, lay India and behind more barbed wire, on the other side, lay Pakistan. In between, on a bit of earth which had no name, lay Toba Tek Singh. [?]

The paradox of how borders simultaneously separate and unite is discussed elsewhere. ${ }^{40}$ The significance of Manto's description lies in describing an existentialist reality-the separation of people living on both sides who had a long history of cultural and social contact-and the paradoxical character of borders being a metaphor of the ambiguities of nation-building. ${ }^{41} \mathrm{He}$ was, in essence, offering a way of correcting the distortions inherent in state-centered national histories. "India" or "Pakistan" were mere territorial abstractions to most people who were ignorant of how Mountbatten's Plan or the Radcliffe Award would change their destinies and tear them apart from their social and cultural moorings. In their world-view, there was no nationalism, religious or composite. They were blissfully unaware that their fate, which had rested in the hands of the exploiting classes for centuries, would be settled after Mountbatten's three days of "diplomacy" leading to the 3rd June Plan, and that the frontiers would be decided by Cyril Radcliffe in just seven weeks and "a continent for better or worse divided." ${ }^{42}$ They had no clue whatsoever that these vain, insensitive and conceited representatives of the Crown, having received the mandate from Clement Atlee's Labor government to preside over the liquidation of the most important impe-

\footnotetext{
${ }^{40}$ Baud and Schendel, p. 242.

${ }^{41}$ See Benedict Anderson, Imagined Communities: Reflections on the Origin and Spread of Nationalism (1983; New York, 199I), and E.J. Hobsbawm and Terence Ramger, ed. The Invention of Tradition (Cambridge, 1983).

${ }^{42}$ This is a line from W.H. Auden, as quoted in Khilnani, p. 200.
} 
rial possession of all time, would abandon them in mid-ocean "with a fire in the deck and ammunition in the hold." Nobody had warned them how Mountbatten's mentor Winston Churchill had, likewise, sat with T.E. Lawrence and the Emir Faisal in Cairo as Colonial Secretary in 1922 drawing nation states on the map of what had previously been the Ottoman Empire. But, then, how were they to know that the colonial powers divide people and territories when in ascendancy, as well as when in retreat.

\section{IV}

For a long time I refused to accept the consequences of the revolution, which was set off by the Partition of the country. I still feel the same way; but I suppose, in the end, I came to accept this nightmarish reality without self-pity or despair. In the process I tried to retrieve from this manmade sea of blood, pearls of a rare hue, by writing about the singleminded dedication with which men had killed men, about the remorse felt by some of them, about the tears shed by murderers who could not understand why they still had some human feelings left. All this and more, I put in my book Siyah Hashye. ${ }^{43}$

Everytime I visited Amritsar, I felt captivated. But the city this time presented the look of a cremation ghat, eerie and stinking. [...] The silence was so perfect that even the faint hiss of steam from the stationary engine sounded a shriek. [...] The brief stoppage seemed to have lingered into eternity till the engine whistled and gave a gentle pull [...] We left Chheharta behind and then Atari and when we entered Wagah and then Harbanspura everyone in the train felt uplifted. A journey through a virtual valley of destruction had ended when finally the train came to a halt at Platform No. 2-Lahore, the moment was as gratifying as the consummation of a dream. ${ }^{44}$

Scores of writers reveal the other face of freedom, the woes of divided families, the agony and trauma of abducted women, the plight of

${ }^{43}$ Saadat Hasan Manto, "Black Margins," in my India Partitioned (Delhi: Roli Books, 1995), vol. I, p. 89 .

${ }^{44}$ Mohammad Saeed, Lahore: A Memoir (Lahore, 1989), p. 94. 
migrants and the harrowing experiences of countless people who boarded trains that would take them to the realization of their dream, but not a man, woman or child of whom survived the journey. A Zahid in Attia Hosain's Sunlight on a Broken Column or a Saddan in Masoom Reza Rahi's $\bar{A} d^{h} \bar{a} G \bar{a}$ 'on (Half-a-Village) offer a vivid and powerful portrayal of a fragmented and wounded society. ${ }^{45}$ What political debate will never fully do-and the reason we so badly need the literature-is defeat the urge to lay blame, which keeps animosity alive. Only literature truly evokes the sufferings of the innocent, whose pain is more universal and ultimately a vehicle of more honest reconciliation than political discourse. ${ }^{46}$

Board the Peshawar Express or the train to Pakistan to discover the implications of what happened before and after the fateful, midnight hour. Consider the exchanges between Choudhry Mohammad Ali, a wellknown landlord of Rudauli in Barabanki district (Uttar Pradesh) and his daughter who left her father to settle in Karachi, or the correspondence of Brahm Nath Dutt, father of the historian V.N. Datta, to capture the poignancy of the moment. Turn to Rahi's Gangauli village-a world where people are seen to be wrestling to come to terms with competing ideologies - in order to uncover the intricate and almost imperceptible way in which the politics of Partition worked its way into the interstices of people's consciousness. ${ }^{47}$ Read Attia Hosain's Sunlight on a Broken Column or Phoenix Fled to discover how the Pakistan movement split families along ideological lines and created fears and uncertainties in the minds of people. To read her novel and collection of short stories is, "as if one had parted a curtain, or opened a door, and strayed into the past." ${ }^{\prime 38}$

Indeed, if the histories of Partition are to be rewritten, there are several reasons why we must judiciously draw upon the intellectual resources made available to us by creative writers who expose the inadequacy of the numerous narratives on Independence and Partition, compel

${ }^{45}$ On $\bar{A} d^{h} \bar{a} G \bar{a}$ 'on, see Sudhir Chandra, "The Harvest of Fear: A Retrospective Critique of Hindu-Muslim Relations in Two Hindi Novels," in Region, Religion, Caste, Gender and Culture in Contemporary India, ed. T.V. Sathyamurthy, (Delhi, 1996), Vol. 3.

${ }^{46}$ Jason Francisco, "In the Heat of Fratricide: The Literature of India's Partition Burning Freshly (A Review Article)," The Annual of Urdu Studies, No. II (Madison: University of Wisconsin, Center for South Asia, 1996), p. 250.

${ }^{47}$ Chandra, p. 195.

${ }^{48}$ Anita Desai, "Introduction," Phoenix Fled (Delhi, I988), p. viii. 
us to explore fresh themes and adopt new approaches that have eluded the grasp of social scientists, and provide a foundation for developing an alternative discourse to current expositions of a general theory on intercommunity relations. Their strength lies in representing a grim and sordid contemporary reality without depicting religion or a particular community as the principal reference point. In their stories, the experiences of each community distinctly mirror one another, indeed reach out to and clutch at one another. No crime, no despair, no grief in exile belongs uniquely to anyone. ${ }^{49}$ In the words of Krishna Sobti, whose best-known Hindi writings on Partition are Sikka Badal Gayā and Zindagināma, a notable feature of the fiction written about that cataclysmic event was that it preserved "essential human values." 50 That is probably why,

we emerge from the literature with a mistrust towards group solidarity of an oppositional bent. If so, we must emerge at the same time, paradoxically, with a conviction to oppose such mistrust with trust in the goodness of the human life-urge wherever we find it. Indeed, we emerge from the literature as searchers of such trust. If we find it in the solitary dissidence of even a single person, we feel obliged to offer him or her our companionship. And if we find it stitched into whole communities, we come away not necessarily more pious, but inspired. The literature as a whole seeds pathos for the suffering and inhumanity of the Partition, and related instances of cultural chauvinism, but not merely so. It also sprouts a countervailing protest, a voice of justice that must be the surging of our humanity itself-something greater than our bestiality—within us. In this sense the literature does what religious leaders in each community failed to do: to make communities forces for the affirmation of humanity broadly [...] If religious politics worked nefariously in favour of Partition, it was because ecumenical religious politics never developed. We are in a different position than the men and women of August, 1947. Our choices are not limited to exile, death or resignation. ${ }^{51}$

In other words, if creative writings can still stir the individual and

\footnotetext{
${ }^{49}$ Francisco, p. 250.

${ }^{50}$ Sen, p. 77, and Alok Bhalla, ed. Stories About the Partition of India, 3 vols. (Delhi, 1994).

${ }^{51}$ Francisco, p. 250. See also the introduction in Muhammad Umar Memon, ed. Intizar Husain: The Seventh Door and Other Stories (Boulder, Colorado: Lynne Rienner, 1998).
} 
collective imagination of sensitive readers in the Subcontinent, there is no reason why people on both sides of the Wagah border cannot share the anguish of Faiz Ahmad Faiz ${ }^{52}$ and, at the same time, echo the optimism and plea of Ali Sardar Jafri in the following lines:

Tum ào gulshan-e Lāhaur sē čaman bardōsh

Hum à'èn șubh-e banāras kĩ raushnì lè kar

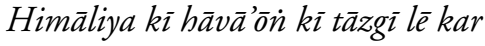

Phir uskē ba'd yeh pūčnèn ke kaun dushman hai

You come covered with flowers from the Garden of Lahore

We bring to you the light and radiance of the morning of Banaras,

the freshness of the winds of Himalayas.

And then we ask who the enemy is. [?]

${ }^{52}$ The anguish which comes through powerfully in his lines:

This leprous daybreak, dawn night's fangs have mangled-

This is not that long-looked-for break of that day,

Not that clear dawn in quest of which those comrades

Set out, believing that in heaven's wide void

Somewhere must be the stars' last halting place,

Somewhere the verge of night's slow-washing tide,

Somewhere an anchorage for the ship of heartache. [?] 